\title{
Adli Bilimlerde DNA Parmak İzine Adli Genetik ve Adli Antropolojik Bakış
}

\author{
Elif ÇETLI $\dot{1}^{1 *}$, Demet TATAR ${ }^{2}$, Vahdet ÖZKOÇAK ${ }^{3}$ \\ ${ }^{1}$ Hitit Üniversitesi, Fen Bilimleri Enstitüsü, Adli Bilimler ABD, Çorum \\ ${ }^{2}$ Hitit Üniversitesi, Ömer Derindere Meslek Yüksek Okulu, Tıbbi Hizmetler ve Teknikler Bölümü, Çorum \\ ${ }^{3}$ Hitit Üniversitesi, Fen- Edebiyat Fakültesi, Antropoloji Bölümü, Çorum \\ (ORCID: 0000-0002-4425-3064) (ORCID: 0000-0002-9317-3263) (ORCID: 0000-0002-4603-2548)
}

\begin{abstract}
$\ddot{O} z$
Suç olaylarının çözümlenmesinde ve suçlunun belirlenmesinde yardımcı olan Adli Bilimler alanı gün geçtikçe önemini arttırmaktadır. Olay yerinden elde edilen deliller aracılığı ile kişilerin tanımlanmasında her kişide farklı yapıya sahip olan DNA molekülü olayları çözüme kavuşturmaktadır. Adli amaçlı olarak da kullanılan DNA molekülü Adli Antropoloji ve Adli Genetik alanında kullanılan ortak moleküldür. Antropoloji insan bilimidir ve insanı tüm yönleri ile ele alır. Adli Antropoloji alanı ise suçlunun tespitinde, kimliği belirsiz cesetlerin kimliklendirilmesinde, yaş, cinsiyet ve etnik kökenin belirlenmesinde yardımcı olmaktadır. Antropoloji içerisinde kullanılan Antik DNA sayesinde geçmiş ile günümüz arasında köprü kurulabilmektedir. Olay yerinde her zaman vücut sıvısı veya biyolojik materyaller yer almaz. Bir iskelet kalıntısından olayın çözümlenmesinde devreye Adli Antropoloji girmektedir. İskeletleri kimliklendirme aşamasında Somatoskopi ve Antropometri teknikleri kullanılmaktadır. Bu iki teknik Adli Antropoloji alanında önemli yere sahiptir. Adli Genetik alanı ise olay yerinde bulunan vücut sıvıları ve biyolojik materyaller ile ilgilenir. Bu sıvıları laboratuvar testlerine tabii tutarak DNA analizlerinin sonuçlanmasını sağlamaktadır. Her iki bilim dalının da suçlunun tespitinde DNA molekülünden yararlandığı görülmektedir. DNA molekülünden elde edilen DNA parmak izi kişiye özgüdür ve bu durum suçlu profillerinin belirlenmesi açısından muazzam bir durumdur. DNA Parmak izi ile ilgili yeni gelişmeler söz konusudur. Yeni geliştirilen Optik Koherans Tomografi Sistemi ve ParaDNA Vücut Sıvısı Kimliklendirme Sistemi, DNA parmak izi üzerinde oldukça olumlu sonuçlar ortaya koymaktadır. DNA'nın geri kazanımı ile ilgili çalışmalar sonucunda ise gizli DNA parmak izi olarak tanımlanan izlerin kolayca elde edilebilmesi sağlanmaktadır. Geri kazanım ile olayların çözümlenmesi kısa sürede olmakta ve bu durum birçok laboratuvarın rutin sırasını değiştirmektedir. Aynı zamanda parmak izinin alınması zor olan materyaller üzerinden parmak izinin profillendirilmesine imkân sağlamaktadır.
\end{abstract}

Anahtar kelimeler: Adli Bilimler, Adli Antropoloji, Adli Genetik, DNA Parmak İzi.

\section{Forensic Genetics and Forensic Anthropological Perspective on DNA Fingerprints in Forensic Sciences}

\begin{abstract}
The field of Forensic Sciences that helps to resolve crime cases and identify the offender is increasing its importance day by day. The DNA molecule, which has a different structure in each person in the identification of individuals by means of the evidence obtained from the crime scene, resolves the events. The DNA molecule used for forensic purposes is a common molecule used in Forensic Anthropology and forensic genetics. Anthropology is the science of Man and it deals with all aspects of man. Forensic Anthropology helps identify the offender, identify unidentified bodies, identify age, gender and ethnicity. Thanks to the ancient DNA used in anthropology, a bridge can be established between the past and present. No body fluids or biological materials are always present at the scene. Forensic Anthropology is involved in the analysis of the case from a skeletal remains. Somatoscopy and Anthropometry techniques are used in the identification phase of skeletons. These two techniques have an important place in Forensic Anthropology. The forensic genetic field deals with body fluids and biological materials found at the scene. These fluids are subjected to laboratory tests and provide the results of DNA analysis.
\end{abstract}

*Sorumlu yazar: elcet41@ gmail.com

Geliş Tarihi: 09.03.2019, Kabul Tarihi: 23.07.2019 
It is observed that both branches of science benefit from DNA molecule in the detection of the offender. DNA fingerprinting from the DNA molecule is unique to the individual, and this is a tremendous case in terms of determining the profile of the offender. There are new developments concerning DNA fingerprints. The newly developed Optical Coherence Tomography System and the ParaDNA body fluid identification system have very positive results on DNA fingerprints. As a result of the studies related to DNA recovery, traces identified as latent DNA fingerprints are easily obtained. Recovery and the solution of events in a short time, this situation changes the routine sequence of many laboratories. It also enables profiling of fingerprints through materials that are difficult to remove.

Keywords: Forensic Sciences, Forensic Anthropology, Forensic Genetics, DNA Fingerprints.

\section{Giriş}

DNA, bazı virüsler hariç bütün organizmalarda kalıtsal bilgileri içerisinde barındıran küçük şifrelerdir. Nükleotit olarak isimlendirilen iki uzun polimerden oluşur. Bu yapılar birbirlerine ester bağları aracıllı̆̆ ile bağlanan şeker ve fosfat gruplarından oluşmaktadır [1]. DNA'nın yapısında adenin, guanin, sitozin ve timin olarak isimlendirilen azotlu bazlar bulunmaktadır. Bu bazlar birbirlerine hidrojen bağları ile bağlanırlar [2].

DNA molekülü genetik bilgileri içermesinden dolayı pek çok alanda kullanılmaktadır. Sağlık alanında kalıtsal temelli hastalıkların analizine olanak sağlarken, Adli Bilimler alanı içerisinde ise suçlunun tespit edilmesi açısından kullanılmaktadır. Adli vakalarda DNA analiz yöntemleri kullanılarak kimliği belirsiz kişilerin kimliklendirilmesinde, babalık - annelik davalarının sonuçlandırılmasında, felaket kurbanlarının kimliklendirilmesinde ve suçlunun olay yerinde bıraktığg biyolojik materyaller üzerinden suçlunun kimliğinin saptanması amacı ile yararlanılmaktadır [3].

Bir toplumun genetik yapısındaki varyasyonların varlığına "genetik polimorfizm" denir. Bir lokus bölgesinin polimorfik olarak adlandırılması için toplum içinde o lokusla ilgili iki veya daha fazla allelin bulunması zorunludur. Kişiler arasında farklılıkların bulunması, yani polimorfizm önemlidir. Olay yeri inceleme sonucu toplanan biyolojik materyalden kimliklendirme yapılmasında, akrabalık ilişkilerinin tespit edilmesinde polimorfizm araştırmacılara önemli katkılar sağlar. Adli Seroloji ve Adli Hemogenetik bu konular üzerinde çalışan bilim dallarıdır [4].

Adli Antropoloji ve Adli Genetik de adli bilimlerin diğer alt dalları içerisinde yer almaktadır. Suç olaylarının çözümlenmesinde, suçlu veya kayıp kişinin belirlenmesinde, maktul, mağdur ve olay yeri arasındaki ilişkinin kurulmasında bu bilim dallarından sıklıkla yararlanılmaktadır. Adli Antropoloji bunu iskelet kalıntıları, yumuşak doku ve kişisel veriler üzerinden yaparken Adli Genetik ise DNA materyallerinin PCR tabanlı analizi ile yapmaktadır [5].

$\mathrm{Bu}$ çalışmanın amacı, DNA parmak izinin Adli Genetik ve Adli Antropoloji alanları içerisindeki ilişkisinin değerlendirilmesi, bu alanlar içerisinde nasıl kullanıldığının saptanması ve DNA parmak izi ile ilgili son gelişmelerin alanda çalışma yapan bilim insanlarına ve araştırmacılara sunulmasıdır.

\section{Adli Antropoloji ve Adli Genetik Alanları}

Adli Antropoloji; iskelet kalıntılarından, yumuşak doku ve kişisel veriler üzerinden biyolojik profil oluşturulmasını sağlayan bilim dalıdır. Profil oluşturma sırasında Fiziki Antropoloji ve Genetik bilgilerinden de yararlanılır. Fiziki Antropoloji'de kullanılan metotların adli vakalara uygulanması sonucunda insan iskeletlerinden yaş, boy, cinsiyet, etnik köken, dişlere ait özellikler ve bireylere ait patolojik bulgular tespit edilebilmektedir [6-7].

Adli Antropolojinin önemli kurallarından birisi olay yerinde bulunan kemiğin bir insana mı yoksa hayvana $\mathrm{m}$ ait olduğunun belirlenmesidir. Bunun yanı sıra karışık insan kemiklerinin birbirinden ayırt edilmesi gerekir. Özellikle bu durum toplu ölüm olaylarında bulunan kişi sayısının minimum düzeyde tespit edilmesini ve bu sayede kaç kişinin kalıntılarına dair bilgi sağladığımız açısından önem arz etmektedir [8].

Somatoskopi ve Antropometri teknikleri, Adli Antropoloji içerisinde değerlendirilen en önemli tekniklerin başında gelir. Bu iki teknikten Somatoskopi tekniğinde cesedin yumuşak dokularından yararlanılarak kimliklendirme yapılırken, Antropometri tekniğinde ise cesedin boy uzunluğu, büst yüksekliği gibi Antropometrik ölçümlerinin alınmasında ve iskelet haline gelmiş cesetlerin kemiklerinden ve dişlerinden alınan Antropometrik ölçülerle kimliklendirmesinde yararlanılır [5]. 
Adli Genetik alanı ise DNA materyalinin adli yönden incelenmesi ile ilgilenir. Adli DNA analizlerinde PCR'a dayalı yöntemler 1990'dan beri kullanılmaya başlanmıştır. Eser miktarda DNA içeren örneklerin analizi mümkün hale gelmiştir. Sonraki çalışmalarda, STR olarak adlandırılan kısa tekrar dizilerinin PCR ile çoğaltılarak incelenebileceği gösterilmiştir. Bu sayede adli amaçlı DNA analizinde yeni bir dönem başlamıştır [9].

\section{Antropolojik Çalışmalarda DNA Analizleri}

\subsection{Antik DNA ve Kullanım Alanları}

Geçmiş döneme ait olan, biyolojik örneklerden toplanan DNA için "geçmişte kalan" anlamına gelen "ancient" ifadesi kullanılır. Türkçe kaynaklarda ise "Antik DNA" olarak geçmektedir [10].

Antik DNA alanındaki ilk çalışmalar 1984 yılında yapılmıştır. Bu çalışmada, zebranın bir alt türü olan quaggadan (soyu tükenmiş) mitokondrial DNA dizileri çıkarılmıştır. 1985 yılında ise Mısır'da bulunan bir müzede 2400 yıllık bir insana ait mumyadan nükleer DNA dizilimi başarı ile yapılmışıı [11].

Antik DNA çalışması ile eski iskelet kalıntılarında arkeolojik, paleontolojik ve antropolojik sorulara yanıt bulunur ve böylece insanın kökeni ve tarihi hakkında bilgi edinilir. Bunun yanı sıra hayvan ve bitki DNA'ları ile yapılan çalışmalar neticesinde geçmişten günümüze yaşayan canlı türleri ve türler arası ilişkiler belirlenerek türlerin kökeni hakkında yapılan çalışmalara katkı sağlanır. Antik DNA bilgisi, popülâsyonlar arasındaki genetik farklılıkların ve gen akışının izlenmesinde, filogenetik ağacın oluşturulmasında ve demografik süreçlerin belirlenmesinde kullanılmaktadır [12].

İnsanda cinsiyeti belirleyen X ve Y kromozomlarıdır. Adli Antropoloji alanı, kimliklendirmeye dayalı çalışmaları kapsadığı için cinsiyet belirlemede önemli bir yer oluşturur. İskeletler üzerinde Antropologlar tarafindan yapılan morfolojik inceleme ile cinsiyet tespiti yapmak mümkündür. İskelet kalıntıları ile yapılacak olan DNA çalışmaları da oldukça önemlidir [13].

Mitokondri organeli kendine özgü DNA molekülüne sahiptir. Halkasal yapıda olan bu DNA molekülüne mitokondriyal DNA (mtDNA) denilmektedir. Mitokondriyal DNA yapısından dolayı çok sayıda polimorfizm içermektedir. Polimorfizm, mitokondriyal DNA'nın protein kodlayan kısmında görülebileceği gibi kodlama yapmayan ancak mitokondriyal DNA'nın kontrol noktasını içeren bölgesinde de görülebilmektedir. Bu çeşitliliğe göre mitokondriyal DNA'lar sinıflandırılmaktadır. Oluşan her bir sinıflandırmaya haploit denilmektedir. Her bir haploit topluluğuna haplogrup denmektedir. Göç yollarının belirlenmesinde haplogruplar sıklıkla kullanılmaktadır. Mitokondriyal DNA ve Y kromozomunda yüzlerce kuşak sonrasında zararsız olan mutasyonlar oluşabilmektedir. Mutasyonlar sonrasında oluşan genetik işaretler bireylerin geçmişe ait ataları ile arasındaki genetik bağı belirlemektedir. Bireyler soylarını devam ettirmek için bu genetik işaretler kuşaktan kuşağa aktarılır ve göç ederek gittikleri popülâsyonlar içerisinde haplogruplar açısından yol belirlenir [12-14].

\section{Adli Genetik Çalışmalarında DNA Analizleri}

Polimorfizmin ortaya çıkabilmesi için genomun belli bölgesindeki baz çiftleri dizisinde değişiklik olması gerekir. Değişikliklerin o popülâsyonda kalıcı olması ve sıklığının \%1'den fazla olması gerekmektedir [15].

1983 'te Kary Mullis'in icat ettiği PCR ile birlikte adli amaçlı kimliklendirme hem daha kolay hem de daha kısa sürede gerçekleşmeye başlamıştır [16]. İnsan genomunda yer alan yaklaşık 3 milyar baz çifti, farklı lokuslarda bulunur ve 25.000-30.000 geni kodlamaktadır. Protein kodlayan kısım tüm genomun hemen hemen \%3'nü oluşturmaktadır. Geri kalan kısım protein kodlamaz ve bu kısım çoğunluk olarak tekrar dizilerinden oluşur [17].

DNA'nın intron bölgelerinde, farklı uzunluklarda nükleotid dizilerinin farklı sayıda, ard arda tekrarlanmasıyla oluşan bölgeler polimorfizm açısından önemlidir. Polimorfik bölgelere ait alleller mutasyonları depolama özellikleri ve gen göçünün analizi için sağlam bilgi oluşturduğundan, bu bölgeler filogenetik çalışmalarda ve insan göç modellerinin oluşturulmasında bilgi kaynağı olarak kullanılmaktadırlar [18]. Ardışık olarak tekrar eden dizilerin tekrar sayıları, toplumu oluşturan bireyler arasındaki farklılıkları ortaya koyduğu için bu polimorfizmler adli amaçlı kimliklendirme işlemleri için kullanılmaktadır [19]. 


\subsection{STR Lokusları ve Kullanım Alanları}

Genom üzerinde yaklaşık olarak bir milyon STR lokusu bulunur [20]. STR dizileri basit ve karmaşık olmak üzere ikiye ayrılırlar. Basit tekrar eden STR'lerde tekrar eden ünite aynıdır. Karmaşık olanda ise farklı tekrar üniteleri vardır. Adli amaçlı olarak genellikle tetranükleotit tekrarlar kullanılmaktadır [21]. STR'ler günümüzde daha kısa DNA fragmanları içermesi nedeni ile kısmen bozulmuş örneklerde bile sonuç alınabilmesi, çalışma kolaylığının olması ve birçok lokusun bir arada çoğalabilmesi, yüksek ayırım gücüne sahip olması gibi özellikleri içermesinden dolayı adli amaçlı kimliklendirmede ve nesep tayininde tercih edilen sistemlerdir [22].

Bir kadının biyolojik materyali yine bir kadına ait biyolojik materyalle karşılaştırılmak istendiğinde, $X$ 'e bağlı belirteçlerin değeri otozomal belirteçlerin değerine eşit çıkar. Eğer erkeğin biyolojik materyali başka bir erkeğe ait biyolojik materyalle karşılaştırılırsa, X'e bağlı belirteçlerin değeri otozomal belirteçlerin değerinden az olacaktır. Karışık biyolojik örneklerde erkek varlığının tespiti için Y-STR'lerin kullanılması uygun iken, kadın varlığının saptanması için X-STR'lerin kullanılması otozomal STR'lere oranla daha etkin olmaktadır [23].

Babalık davalarında sadece otozomal STR'lerın kullanımı yeterlidir. Baba ve oğul ilişkisi belirlendiğinde X STR'ler kullanılamaz. Çünkü baba ve erkek çocuk arasında X kromozomu geçişi söz konusu değildir [24].

Baba adayının ölmesi ya da bulunamaması durumunda çocuğun kız olması şartı ile babaanne ve kız çocuk arasında X-STR analizleri ile babalık davaları çözüme kavuşur. Çünkü çocuğun X kromozomlarından biri babasından gelir ve babasının X kromozomu da onun annesinden gelir. Kız çocuktaki babadan gelen X kromozomu kesin bir şekilde babaannenin X kromozomlarından biridir [23]. Cinsel saldırı olgularında Y-STR analizi suçlunun belirlenmesinde etkili bir yöntemdir. Karışmış örneklerde erkekte bulunan Y kromozomu üzerindeki bölgelere özgü primerler kullanılarak Y-STR analizi yapılabilmektedir [3].

\section{DNA Parmak İzi İle İlgili Son Gelişmeler}

\subsection{Optik Koherens Tomografi İle Yapışkan Bant Altında Gizli Parmak İzi Tespiti}

Yapışkan bantlar; tecavüz, cinayet, kaçırma ve patlayıcı maddeler de dâhil olmak üzere adli olaylarda yaygın olarak kullanılmaktadır. Örneğin şüpheli kurbanın ağzını ve ellerini bağlamak istediğinde, yasadışı mallarla paketleri mühürlemek istediğinde veya patlayıcı cihazlar üretirken telleri izole etmek için yapışkan bantlar kullanılır [25]. Bir suç mahallinde bulunan yapışkan bantlar genellikle birbirine yapışır veya belirli bir alt tabakaya bağlanır. Başka bir deyişle, yapışkan tarafına yerleştirilen gizli parmak izlerine sahip yapışkan bant parçası, başka bir bant parçasına veya bir karton gibi belirli bir alt tabakaya bağlanır. Sonuç olarak, gizli parmak izleri iki yapışkan bant şeridi arasında sıkıştırılır [26].

Birbirine yapışmış bantların mekanik olarak ayrılması, bantların orijinal durumuna zarar verir ve gizli baskıları rahatsız eder. Buhar 1sısı, kimyasallar ve soğutma ile dondurma gibi diğer fiziksel veya kimyasal yöntemler de bant ayrılması için kullanılmaktadır [27].

Optik koherens tomografi (OCT) ise Adli Tipta yeni olan ve yüksek çözünürlüklü bir optik görüntüleme tekniğidir [28]. OCT, ses yerine kızılötesi 1şık kullanılması dışında ultrason görüntülemesine benzer. OCT, yerinde ve gerçek zamanlı olarak mikron ölçeğinde örnek yapının kesitsel görüntülerini sağlayabilir. Ayrıca, numuneye zarar vermeyen bir optik biyopsi türü olarak işlev görür. Bu nedenle, bu teknik Adli Bilim çalışanları için güçlü bir araçtır [29].

Deneylerde en sık kullanılan üç yapışkan bant türü vardır. Bunlar; elektrik bantları, kutu sızdırmazlık bandı ve şeffaf Scotch bandıdır (Şekil 1). Bunlardan uygun olanı seçilir ve iç kısmı elde etmek için dokuz parmak izi numunesi hazırlanır. $6 \mathrm{~mm}$ çözünürlük ve gerçek zamanlı iki boyutlu (2D) kesit görüntüleme hızı elde edilen, elle tutulan bir prob ile özel bir spektral etki alanı OCT (SD-OCT) sistemi benimsenmektedir. Üç boyutlu (3D) sekiz rekonstrüksiyonlar uygulanarak ve gizli parmak izlerinin yer altı tabakasındaki her numunenin yüzey (enine kesit) görüntüleri sunulmaktadır. Sonuçlar, numunenin orijinal fiziksel ve kimyasal durumunu korurken, yapışkan bantların altında gizlenmiş gizli parmak izlerinin hassas görüntülerini hılı bir şekilde tespit edebildiğini ve kurtarabildiğini göstermektedir. OCT'nin yapışkan bant altında olmayan yıkıcı ve hızlı algılama şeklinin, gizli parmak 
izi geliştirmek için güvenilir bir rehber ve tamamlayıc1 yöntem olduğu belirtilmiştir (Şekil 2, Şekil 3, Şekil 4) [ 30].

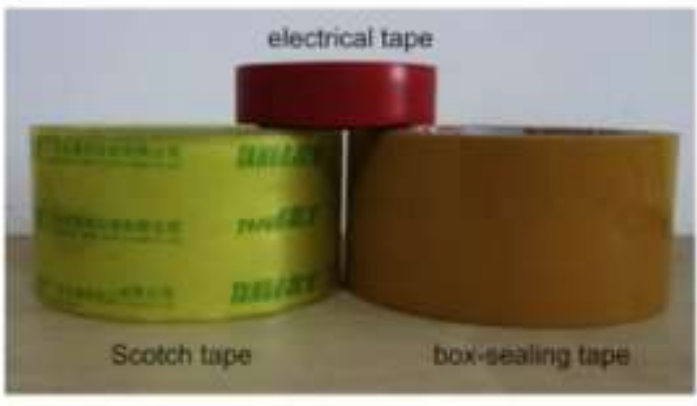

(a)

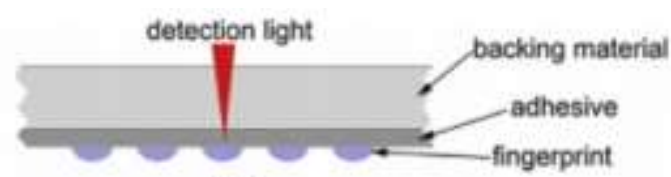

(b)

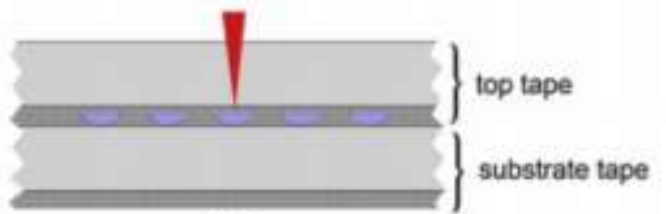

(c)

Şekil 1. a) Elektrik bandı, Kutu sızdırmazlık bandı, Şeffaf Scoth bant görüntüsü b) Yapışkan tarafinda parmak izi bulunan tek bant parçasının diyagramı c) İki parça bant arasında sıkışmış gizli parmak izi diyagramı.
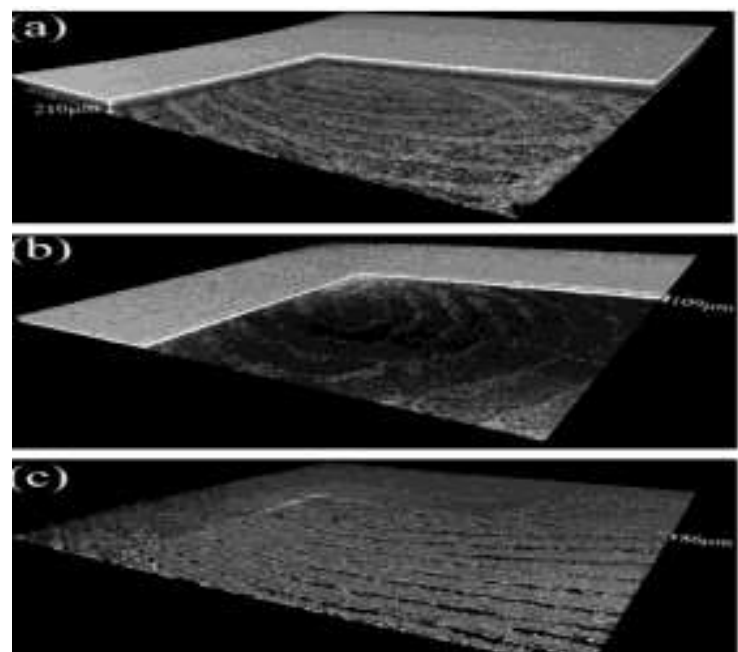

Şekil 2. a) Örnek 1 b) Örnek 2 c) Örnek 3 d) $210 \mu \mathrm{m}$ e) $109 \mu \mathrm{m}$ f) $86 \mu \mathrm{m}$ derinliğinde çıkarılan, karşıl1k gelen en yüz görüntülerinin köşe kesim 3D görünümleri
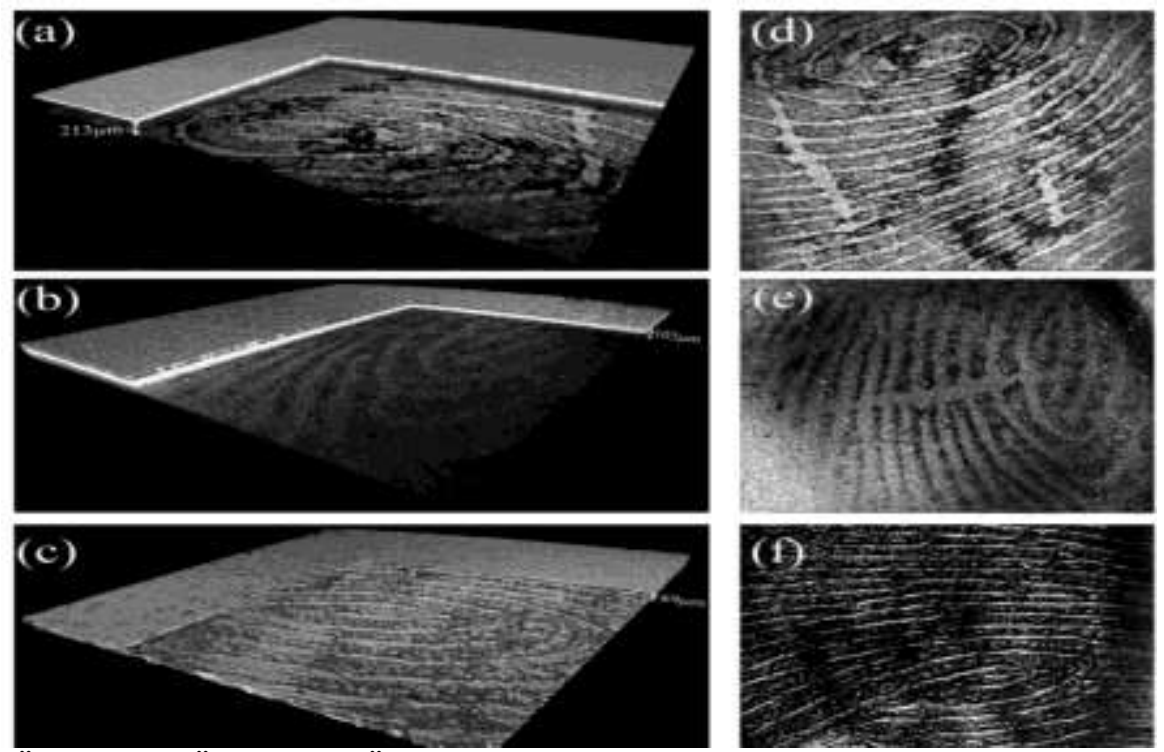

Şekil 3. a) Örnek 4 b) Örnek 5 c) Örnek 6 d) $213 \mu \mathrm{m}$ e) $103 \mu \mathrm{m}$ f) $89 \mu \mathrm{m}$ derinliğinde çıkarılan, karşıl1k gelen en yüz görüntülerinin köşe kesim 3D görünümleri 

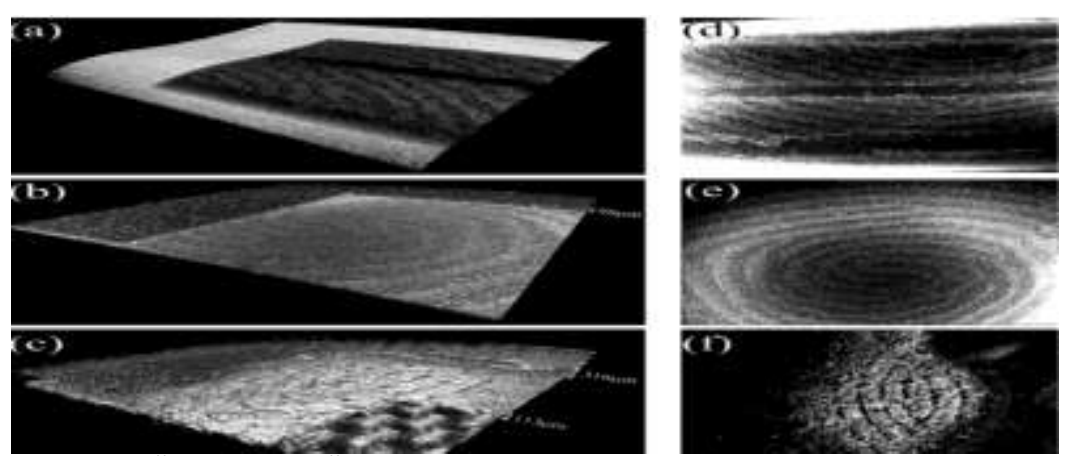

Şekil 4. a) Örnek 7 b) Örnek 8 c) Örnek 9 d) $205 \mu \mathrm{m}$ e) $96 \mu \mathrm{m}$ f) $316 \mu \mathrm{m}$ derinliğinde çıkarılan, karş11ık gelen en yüz görüntülerinin köşe kesim 3D görünümleri

\subsection{ParaDNA Vücut Sıvısı Kimliklendirme Sistemi}

Biyolojik sıvılar, suç soruşturmalarında hayati kanıtlar sağlar. Biyolojik sıvıların tanımlanması önemlidir ve malzemenin kaynağı olay yerinde, olayların yeniden yapılandırılması ve canlandırılması için oldukça kritik bir öneme sahiptir. Ayrıca, bir laboratuvara gönderilmeden önce biyolojik materyali hızla tanımlamaya, araştırmacıların DNA ekstraksiyonu ve profil oluşturma için en uygun örnekleri göndermelerini sağlayacak bir mekanizma sağlamak için ihtiyaç duyulur. Geleneksel vücut sıvısı tanımlama yöntemleri genellikle uzun, çok aşamalı, laboratuvar tabanlı mikroskopi veya immünolojik, kimyasal veya tüm vücut akışkanlarının tanımlanmasına izin vermeyen enzimatik deneylerdir ve bu testlerin birçoğunda çapraz reaktivite ile ilgili sorunlar ortaya çıkmaktadır. Bu nedenle sadece varsayımsal sonuçlar sunmaktadır [31].

Tüm ilgili vücut sıvılarının adli olarak kesin tanımlanabilmesi için daha kesin, moleküler tabanlı yöntemler geliştirmeye yönelik önemli araştırmalar yapılmıştır. Bu yöntemlerden bazıları spesifik protein belirteçleri, DNA metilasyon belirteçleri veya mikro RNA'yı hedeflemektedir [32]. Mesajc1 RNA (mRNA) analizi en köklü moleküler vücut sıvısı tanımlama yaklaşımıdır ve kesin olarak bir vücut sıvısını tanımlayan doğrulayıcı bir test olarak da kabul edilir. Adli Bilimlerde ilgili tüm vücut sıvılarını tanımlamak için bir dizi spesifik ve hassas mRNA tahlili geliştirilmiştir [33].

Daha sonra bilim insanları tarafından ParaDNA Vücut Sıvısı Kimliklendirme Sistemi geliştirilmiştir. ParaDNA Vücut Sıvısı Kimliklendirme Sistemi, termal döngü kullanılarak floresans ışık altında numunelerin tespit edilmesini sağlayan bir cihaz ve numune toplayıcısı ve toplanan numunelerinin kullanımına hazır bir kitten oluşmaktadır. ParaDNA Vücut Sıvısı Kimliklendirme Testi gerçek zamanlı PCR ve erime eğrisi tespiti için gerekli tüm reaktifler ile önceden yüklenmiş, özel olarak tasarlanmış bir plakadır. Test aynı anda altı mRNA vücut sıvısı işaretleyicisini büyütür ve tespit eder. $\mathrm{Bu}$ vücut sıvıları şu şekildedir; periferik kan, seminal sıvı, sperm hücreleri, tükürük, vajinal sıvı ve regl kanıdır. Tek adımlı, kullanımı kolay, hızlı, mevcut ParaDNA enstrümanları doğrulayıcı test üzerinde çalışmakta ve laboratuvar bazlı ekstraksiyon teknikleri gerektirmemektedir. ParaDNA yazılımı, 90 dakikanın hemen altında, hem ekranda hem de yazdırılabilir bir PDF raporu olarak sıvıların tespit edildiği açık bir gösterge sağlamaktadır [32-34].

Vücut sıvısı tanımlama için mRNA analizi daha doğrulayıcı sonuçlar sağlar. Bunun yanı sıra ParaDNA Vücut Sıvısı Kimlik Sistemi sayesinde vücut sıvılarının kolayca ve hızlı bir şekilde tanımlanması kolaylaşmaktadır. ParaDNA Vücut Sıvısı Kimliklendirme Testi, vücut sıvılarından elde edilen kanıt öğelerinin mevcut hızla onaylamak amacıyla, adli soruşturma süreçlerini desteklemek için kullanılabileceğini göstermektedir. (Şekil 5, Şekil 6) [35-36]. 


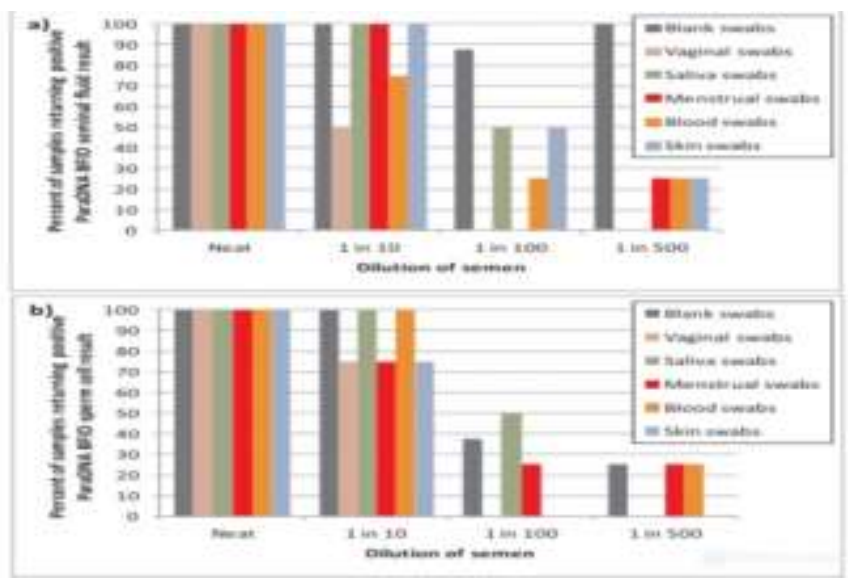

Şekil 5. Pozitif ParaDNA vücut sıvısı kimliği a) seminal sıvı b) sperm hücrelerinin geri dönen örneklerin yüzdesi, bu yüzde boş sürüntüler dışında her koşul için $50 \mu 1$ sperm seyreltme aralığı ile çeşitli boş ve doymuş örnek sürüntülerden kaynaklanır

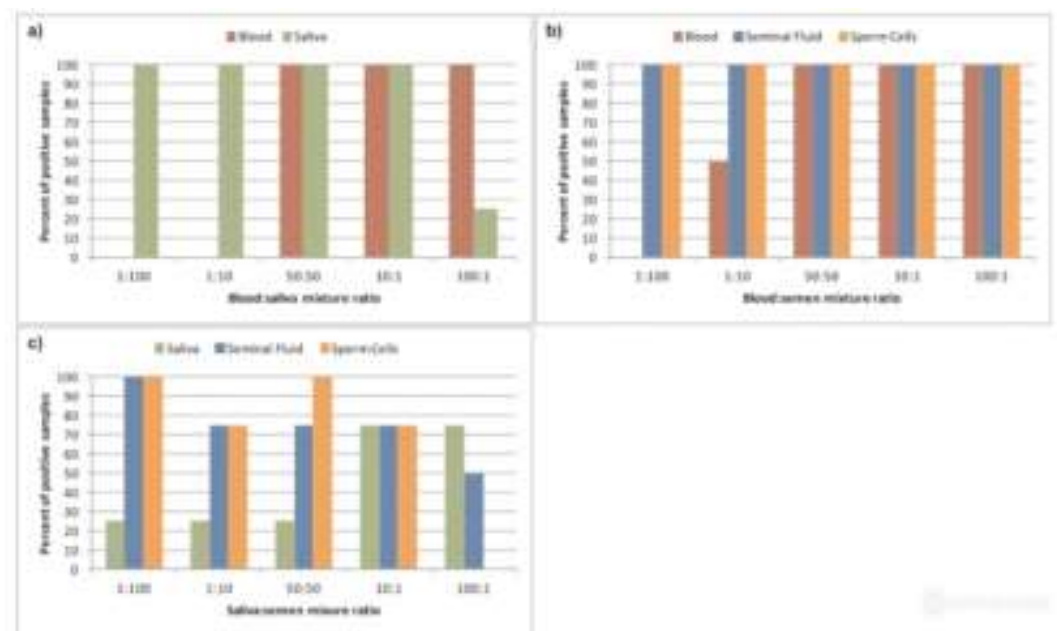

Şekil 6. Pozitif ParaDNA vücut sıvısı veren örneklerin yüzde kimliği a) kan ve tükürük karışım oranları bir dizi sıvıların her biri için sonuçlar b) Kan ve semen c) tükürük ve meni

\section{Tartışma}

Adli DNA fenotipleme, olayların çözüme kavuşması için gerekli olan bir işlemdir. Olay yerinden alınan biyolojik materyaller ve vücut sıvılarından DNA analizleri yapılarak suçlunun kimliğinin belirlenmesi gerekmektedir. Fenotipleme tekniklerinin geliştirilmesi ile DNA analiz sonuçlarının kesinliği artırılmaktadır. Bu konuda literatürde çeşitli araştırmalar yer almaktadır.

Sinelnikov ve Reich çalışmalarında, fenotiplemelerde kullanılan standart prosedür üzerinde bazı değişiklikler yaparak, fenotipleme için yeni prosedür geliştirmişlerdir. Geliştirdikleri genel prosedür, Adli Tıp için kullanılan prosedürdür. Protokolde bez parçalarından kanıt toplama, proteolitik sindirim, DNA arıtma, amplifikasyon ve analiz kısımları yer almaktadır. Akım işleminde yaptıkları değişiklikler ile prosedürde örnek toplama, DNA arıtma ve POST-PCR adımlarının verimliliğini artırdıklarını kanıtlamışlardır. Deterjan bazlı toplama tamponu kullanarak, suyun aksine, DNA toplama verimliliğinde önemli bir gelişme olduğunu ve yüzey alanı başına gereken sıvı hacmini azalttıklarını belirtmişlerdir (Şekil 7) [37]. 


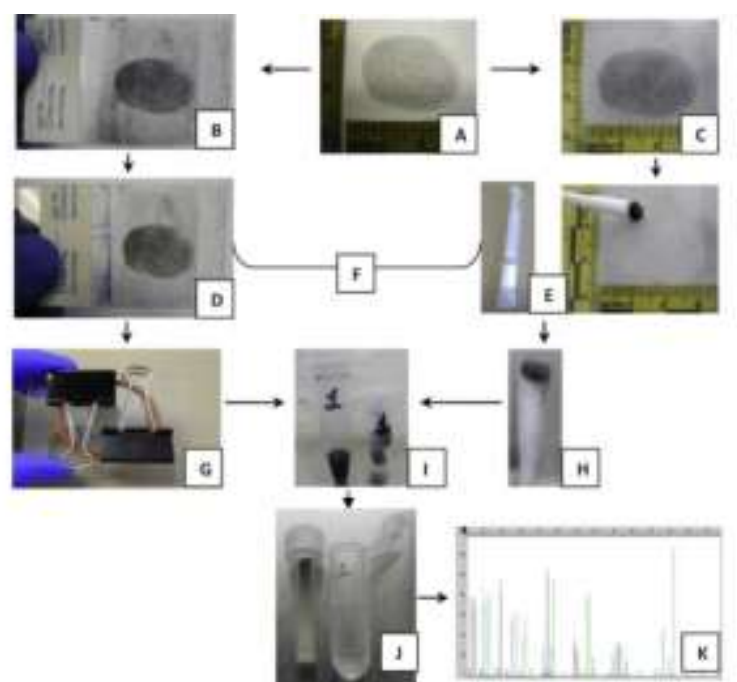

Şekil 7. İş akışı şematiği: Gizli parmak izlerinden DNA profilleri. A) başlangıç malzemesi: toz (parmak izi) ile geliştirilmiş gizli parmak izi. B) Menteşe kartındaki parmak izinin kaldırılması. C) Gizli parmak izi kanıt kaldırma üzerinde bıraktıkları. D) Asansör kartındaki Parmak izine maruz kalındığında, eldiven ile elle tutulan şeffaf astarın not edilmesi. E) Swab ve koleksiyon tamponunu kullanarak geri DNA kazanım' materyalinin toplanması. F) Parmak izi kanıt = kaldırma kartı + geri kalan malzeme toplanımını temsil eder. G) Lizis odasındaki hareketsiz kaldırma kartı, o-ring, bağlayıcı klipslerin not edilmesi. H) Sol arka malzemeyi kurtarmak için kullanılan çubuğun kuluçka lizis odasından özü toplamak için kullanılması. I) Spin sepetinden sonra elde edilen toplam lizat; bu materyalde ikinci bir proteolitik sindirim yapılmaktadır. J) Kombine lizat = asansör kartından lizat + XS sütununda saflaştırılmış ayrılmış sürüntü lizat; sütun (sol) ve temiz saflaştırılmış lizat (sağ) içinde muhafaza tozun not edilmesi. K) CE GeneScan elektroferogramı analiz PowerPlex 16 PCR reaksiyonu

Diğer yönden elde edilen materyallerin cinsi ve kurtarılan DNA miktarları arasında bir ilişki bulunmaktadır. DNA parmak izinin geri kazanımı parmak izlerinin alınmasının mümkün olmadığı materyaller üzerinde etkili olmaktadır. DNA geri kazanımı sayesinde çeşitli koşullarda az miktarda DNA’nın bile suçluyu tanımlamak için yeterli olduğu görülmüştür.

Sewell ve arkadaşları çalışmalarında, kâğıt üzerinden elde edilen parmak izinin geri kazanımının yüksek miktarda gerçekleşmesi için iki DNA kiti karşılaştırmışlardır. Bu DNA kitleri DNeasyl bitki mini kiti ve QIAAMP1 mini kitidir. Bu çalışma sonucunda DNeasy1 bitki mini kitinin kâğıttan DNA çıkarmak için etkili bir yöntem olduğu kanıtlanmıştır ve ağartılmamış filtre kâğıdı, dergi ve gazete gibi kâğıt türleri, aktarılan DNA'nın daha fazla iyileşmesine izin vermektedir (Şekil 8 Şekil 9) [38].

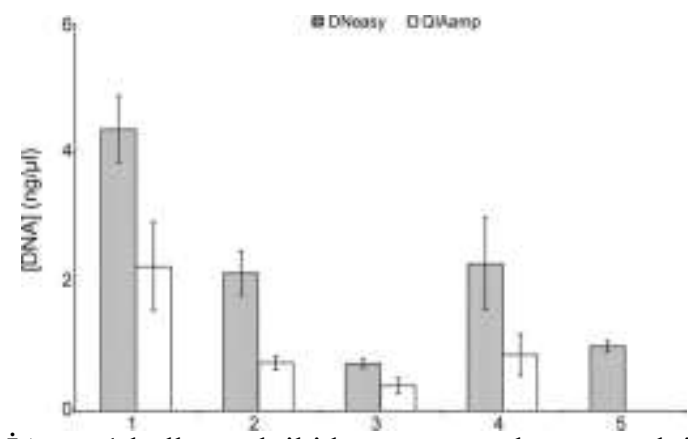

Şekil 8. DNAASY1 ve QİAamp1 kullanarak iki kağıt türü ve beş parmak izi üzerinde tükürük çeşitli miktarlarda DNA kurtarma (ng/ml) karşılaştırılması. Hata çubukları standart hatayı gösterir, $\mathrm{N}=4$. Tedaviler:

(1) $20 \mathrm{ml}$ tükürük (Whatman1); (2) $10 \mathrm{ml}$ tükürük (Whatman1); (3) $5 \mathrm{ml}$ tükürük (Whatman1); (4) $5 \mathrm{ml}$

(Whatman1); (5) $20 \mathrm{ml}$ tükürük (ofis kağıdı) 


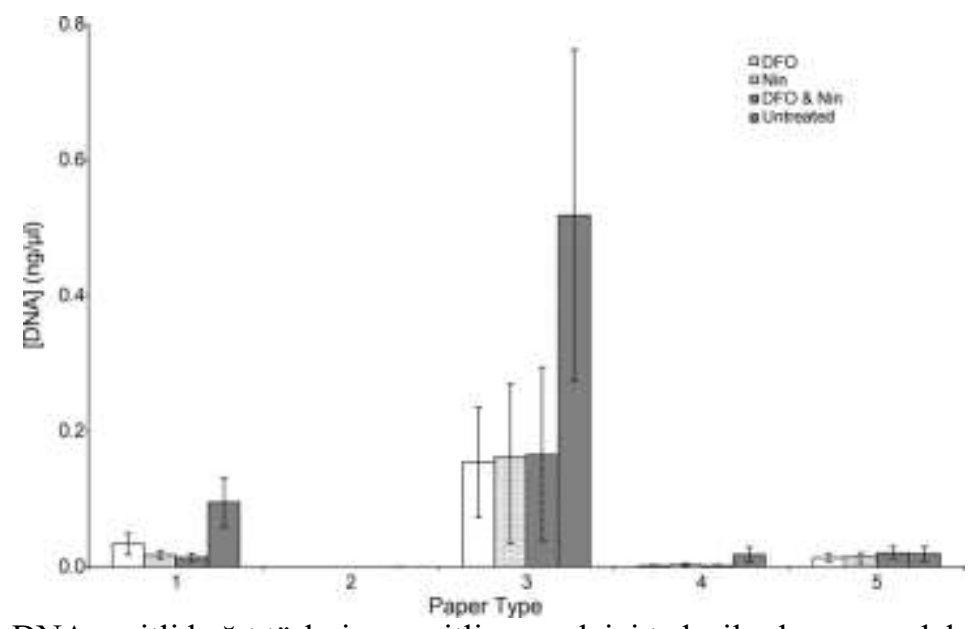

Şekil 9. Ortalama DNA çeşitli kağıt türleri ve çeşitli parmak izi tedavilerden sonra dokunulan belgelerden (ng/ml) kurtarıldı. Çubuklar standart hatayı gösterir, $\mathrm{N}=6$. Kağıt türleri: (1) filtre kağıdı; (2) ofis kağıdı; (3) dergi; (4) kart; (5) gazete

Feine ve arkadaşları çalışmalarında elektrik bantlarından DNA geri kazanımının mümkün olduğunu göstermiş̧lerdir. Bomba ve patlayıcı maddelerde sıklıkla kullanılan elektrik bantlarının yapışkan yüzeylerinde gizli parmak izi bıraktığını ortaya koymuşlardır. Bu çalışma sonucunda elektrik bantları üzerinde iki DNA kurtarma yönteminin karşılaştırılmasını yaparak sonuçlarında iki aşamalı aseton-su geri kazanımının avantajlarını açıkça göstermiştir. Bu yöntem ile aynı zamanda, büyük yüzey alanı yapıştırıcılarının yanı sıra örnekleme için kullanılan yapışkan bantlardan DNA'yı kurtarmak için ölçeklendirme yapılabileceğini belirtmişlerdir (Şekil 10) [39].
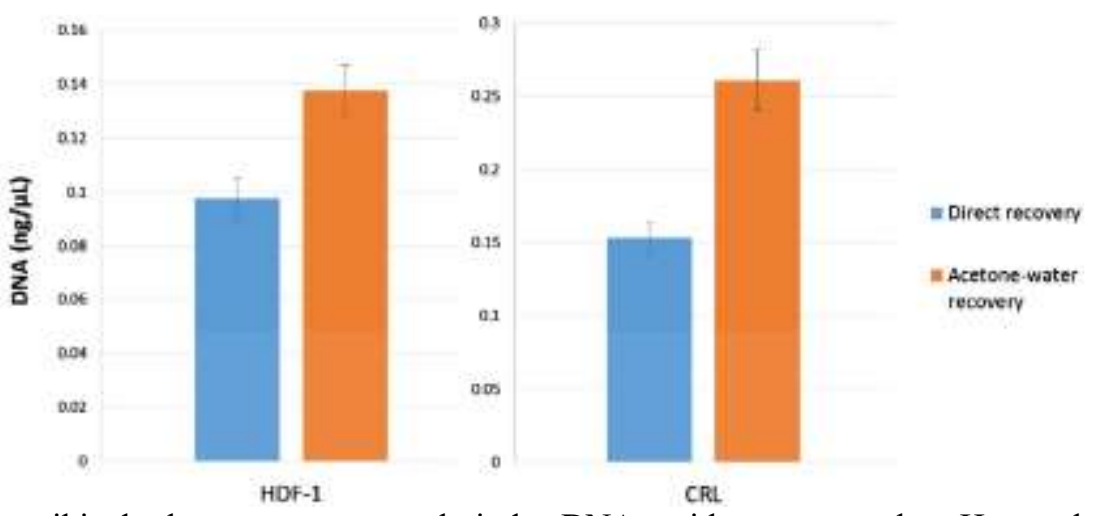

Şekil 10. Doğrudan ve iki adımlı aseton-su yöntemlerinden DNA geri kazanım oranları. Hücresel materyal ile yüklenen Elektrik bantlarından DNA, doğrudan ekstraksiyon ile veya iki adımlı aseton-su yöntemiyle kurtarıldı.

Sonuçlar ortalama DNA konsantrasyonunu temsil eder

Ostojic ve Wurmbach yaptıkları çalışmalarında, 900'den fazla parmak izi örneklerini incelemişlerdir. Parmak izinin hangi maddelerde daha fazla aktarıldığına ve geri kazanımına bakmışlardır. Bunun sonucunda cam plastikten, kâğıdın daha iyi sonuçlar verdiğini ortaya koymuşlardır. Numunenin karmaşıklığını azaltarak karışmış halde bulunan DNA örneklerinde bile yararlı sonuçlar vereceğini belirtmişlerdir [40].

$\mathrm{Bu}$ çalışmalar sonucunda Adli fenotiplemenin, suçlunun bulunması açısından büyük önem arz ettiğini söyleyebiliriz. DNA'nın bazı alanlardan geri kazanımının olması, DNA parmak izinin varlığı, adli olayların daha kısa sürede çözülebileceğini göstermektedir. DNA geri kazanımı sayesinde her yüzeyden başarılı bir şekilde DNA parmak izinin alınması ve geri kazanım miktarının artırılması ile ilgili çalışmaların artarak devam etmesi gerektiği düşüncesindeyiz. 


\section{Sonuç}

DNA molekülü hem Genetik alanda hem de Antropolojik alanda önemli bir yere sahiptir. Bu molekül suçlunun tanımlanması açısından en doğru bilgilere ulaşmamızı sağlamaktadır. Antropoloji insan bilimidir ve insanı içeren tüm olaylarla ilgilenir. Adli Antropoloji ise suç yönünden kimliklendirme yapılması açısından adaletin doğru bir şekilde tecelli etmesinde görev almaktadır. Gerek Antropometri gerekse Somatoskopi teknikleri olsun iskelet kalıntılarının kimliklendirilmesi, cinsiyet tayininin yapılması, boy, yaş, etnik kökenin belirlenmesi ve yumuşak dokudan adli vakaların aydınlatılmasında bu bilim dalının katkısı oldukça önemlidir.

Adli Antropoloji alanının parçası olan Antik DNA sayesinde geçmişte yaşayan ve nesli tükenmiş türler ile günümüzde yaşayan türler arasında köprü kurulması mümkün olmaktadır. Antik DNA göç yollarının belirlenmesinde, eskiden var olan hastalıkların tanımlanmasında, atalarımız ile soy bağımızın araştırılmasında bilim insanlarına ve araştırmacılara yarar sağlamaktadır.

Adli Genetik ise DNA molekülünü, kişilerin tanımlanmasında kullanmaktadır. Olay yerinden elde edilen biyolojik materyallerin kimliklendirilmesini DNA profillerinin çıkarılıp suçlunun tespit edilmesinde yardımcı olmaktadır. Gerek Adli Antropoloji gerekse Adli Genetik olsun ikisinin de ortak noktası insanın tanımlanması ve suçlunun tespitinin yapılmasına doğrudan katkı sağlamasıdır. $\mathrm{Bu}$ sebeple iki bilim dalı da Adli Bilimler içerisinde oldukça fazla öneme sahiptir.

DNA parmak izi olayın aydınlatılması açısından bize çok büyük imkânlar sunmaktadır. Çünkü DNA parmak izi kişiye özgüdür ve bu da suçlu profilinin sağlam ve doğru bir şekilde ortaya çıkmasını sağlamaktadır. Son zamanlarda teknolojinin de imkân tanıması ile DNA parmak izi ile ilgili gelişmeler çok hızlı bir şekilde ele alınmaktadır. Optik Koherens teknolojisi ve ParaDNA Vücut Sıvısı Kimliklendirme Sistemleri, DNA parmak izi aracılığıyla suçlunun daha kolay bir şekilde tanımlanması için oluşturulan yeni gelişmelerdir. DNA'nın geri kazanımı konusu ise çok önemlidir. Zarar görmüş veya alınması mümkün olmayan materyallerden geri kazanımın yapılması ve bu sayede bazı alanlardan DNA geri kazanımının olması suç analizlerinin kısa zamanda ve daha kolay sonuçlanmasına imkân sağlamaktadır.

$\mathrm{Bu}$ alanda yapılan genel çalışmaları değerlendirdiğimizde DNA geri kazanım işlemlerinin, Adli Bilimler açısından özellikle de Adli Antropoloji ve Adli genetik alanlarında, suç tespitlerinde kolaylık sağlayacağı açıkça bellidir. DNA geri kazanımının artması ve uygulama prosedürleri içerisinde yer alması açısından veri tabanlı sistemlerin kurulması ve DNA parmak izinin her alandan alınmasını kolaylaştıracak yöntemler ile suç tespitinde çözülmemiş olay kalmaması açısından çalışmaların ivmelenerek artması gerektiği görüşündeyiz.

\section{Kaynaklar}

[1] Meyer E.F. 1997. The First Years of the Protein Data Bank. Protein Sci., 6 (7): 1591-1597.

[2] Crick F. 1970. Central Dogma of Molecular Biology. Nature, 227 (5258): 561-563.

[3] Graw M., Setiz T. 2000. Y Chromosomal Short Tandem Repeat (Str) Loci in A Representative Group of Males Living in South Württeemberg: A Database For Application in Forensic Medicine. For. Sci. Int., 113: 43-46.

[4] Rudin N., Inman K, 2002. An İntroduction to Forensic Dna Analysis. ${ }^{\text {th }}$ Ed. Crc Press Boca, p. 53-90.

[5] Özkoçak V., Akın G., Gültekin T. 2017. Somatoskopi ve Antropometri Tekniklerinin Adli Bilimler için Önemi. Hitit Üniversitesi Sosyal Bilimler Dergisi, (10): 703-714.

[6] Çeker D. 2017. İnsan Kemiklerinin Analizi ve Adli Antropoloji'de Kimliklendirmede Önemi. Masrop E - Dergi, 11 (17): 8-13.

[7] Özdemir F., Özkoçak V. 2018. Anadolu Erkeklerinde Sağ ve Sol Kulak Kepçesinin Yaşa Göre Değişimi. Turkish Studies Social Sciences, 13 (18): 1047.

[8] Andelinovic S., Sutlovic D., Ivkosic I.E., Skaro V., Ivkosic A., Paic F., Rezic B., Gojanovic M.D., Primorac D. 2005. Twelve-Year Experience in Identification Of Skeletal Remains from Mass Graves. Croatian Medical Journal, 46: 530-539.

[9] Goodwin W., Linacre A., Hadi S., 2007. An Introduction to Forensic Genetics. ${ }^{\text {st }}$ ed. John Wiley \& Sons Ltd Published England, p. 51-61. 
[10] Hummel S. 2003. Ancient DNA Typing: Methods, Strategies and Applications. $1^{\text {th }}$ ed. Springer Verlag Publisher, Berlin, p. 57-80.

[11] Pääbo S. 1985. Molecular Cloning of Ancient Egyptian Mummy DNA. Nature 314(6012): 644645.

[12] Singh J., Garg A. 2014. Ancient DNA Analysis and ,Its Probable Applications in Forensic Anthropology. J Punjab Acad Forensic Med Toxicol., 14 (1): 43-50.

[13] Stone A.C. 2008. DNA Analysis of Archaelogical Remains. Chapter 15. Biological Anthropology of the Human Skeleton, Katzenberg M.A, Saunders S.R., p. 461-482.

[14] Eken B.F., Yayman D.Y, Sercan C., Kapıcı S., Ulucan K. 2018. Spor Genomiğinde Mitokondrial DNA Çalışmaları. ACU Sağlık Bilimleri Dergisi, 9 (4): 339-343.

[15] Dib C. 1996. A Comprehensive Genetic Map of the Human Genom Based on 5,264 Microsatellites. Nature, 380: 152-154.

[16] Kobilinsky L., Liotti T.F., Oeser-Sweat J. 2005. Forensic DNA Analysis Methods, DNA: Forensic And Legal Applications, $1^{\text {st }}$ ed. John Wiley \& Sons, Inc Publication, p. 70-73.

[17] James H.S., Nordby J.J., Bell S. 2014. Forensic Science: An Intraduction to Scientific and Investigative Techniques. $4^{\text {th }}$ ed. Crc Press Florida, p. 115-134.

[18] Gomolka M., Hundrieser J., Nürnberg P., Roewer L., Epplen J.T, Epplen C. 1994. Selected DiAnd Tetranucleotide Microsatellites From Chromosomes 7, 12, 14, and Y in Various Eurasian Populations. Hum. Genet., 93: 592-596.

[19] Schleif R. 1993. Genetics and Molecular Biology. $2^{\text {th }}$ ed. The Johns Hopkins University Press USA, p. 698.

[20] International Human Genom Consortium. 2001. Initial sequencing and Analysis of Human Genom. Nature, 409: 860-921.

[21] Butler J.M., Schoske R., Vallone P.M., Redman J.W., Kline M.C. 2003. Allele Frequencies for 15 Autosomal STR Loci on U.S. Caucasian, African American, and Hispanic Populations. Journal of Forensic Science, 48: 908.

[22] Butler J.M. 2005. Forensic DNA Typing Biology, Technology, and Genetics of STR Markers. 2 th ed. Elsevier Academic Press Burlington, MA, USA, p. 87-117.

[23] Szibor R. 2007. X-Chromosomal Markers: Past, Present and Future. Forensic Science International: Genetics, 1: 93-99.

[24] Szibor R., Krawzak M., Hering S., Edelmann J., Kuhlisch E., Krause D. 2003. Use of XLinked Markers for Forensic Purposes. International Journal of Legal Medicine, 117: 67-74.

[25] Causin V. 2015. Polymers on the Crime Scene. Springer International Publishing, 105-166.

[26] Bramble S.K., Cantu A.A., Ramotowski R.S., Brennan J.S. 2000. Deep Red to Near Infrared (NIR) Fluorescence Of Gentian Violet-Treated Latent Prints. Journal Forensic Identif, 50 (1): $33-$ 49.

[27] Choudhry M.Y., Whritenour R.D. 1990. A New Approach to Unraveling Tangled Adhesive Tape for Potential Detection Of Latent Prints and Recovery of Trace Evidence. J. Forensic Sci., 35 (6): 1373-1383

[28] Fujimoto J.G., Pitris C., Boppart S.A. 2000. Optical Coherence Tomography: An Emerging Technology for Biomedical Imaging and Optical Biopsy. Neoplasia, 2 (1-2): 9-25.

[29] Choi W.J., Min G., Lee H.B. 2000. Counterfeit Detection Using Characterization of Safety Feature On Banknote With Full-Field Optical Coherence Tomography. Journal of the Optical Society of Korea, 14 (4): 316-320.

[30] Zhang N., Wang C., Sun Z., Li Z., Xie L., Yan Y., Xu L., Guo J., Huanq W., Li Z., Xue J., Liu H., Xu X. 2018. Detection of Latent Fingerprint Hidden Beneath Adhesive Tape by Optical Coherence Tomography. Forensic Science International, 287: 81-87.

[31] Vennemann M., Scott G., Curran L., Bittner F., Tobe S.S,. 2014. Sensitivity and Specificity of Presumptive Tests for Blood, Saliva and Semen. Forensic Sci. Med. Pathol., 10: 69-75.

[32]. Hanson E., Ballantyne J. 2013. Highly Specific Mrna Biomarkers for the Identification of Vaginal Secretions in Sexual Assault Investigation. Sci Justice, 53: 14-22.

[33] Haas C., Hanson E.K., Morling N., Ballantyne J. 2011. Collaborative EDNAP Exercises on Messenger RNA/DNA Co-Analysis for Body Fluid Identification (Blood, Saliva, Semen) and STR Profiling. Forensic Sci. Int.: Genet. Suppl., 3: 5-6. 
[34] Hass C., Muheim C., Kratzer A., Bar W., Maake C. 2009. Mrna Profiling for the Identification of Sperm and Seminal Plasma. Forensic Sci. Int. Genet. Suppl. Ser., 2: 534-535.

[35] Juusola J., Ballantyne J. 2005. Multiplex Mrna Profiling for the Identification Of Body Fluids. Forensic Sci. Int., 152: 1-12.

[36] Blackman S., Allen B.S., Hanson E.K., Panasiuk M., Brooker A.L., Rendell P. 2018. Developmental Validation of The Paradna Body Fluid ID System A Rapid Multiplex MrnaProfiling System for the Forensic Identification of Body Fluids. Forensic Science International: Genetics, 151-156.

[37] Sinelnikov A., Reich K. 2017. Materials And Methods That Allow Fingerprint Analysis and DNA Profiling from the Same Latent Evidence. Forensic Science International: Genetics Supplement Series, 6: 40-42.

[38] Sewell J., Quinones I., Ames C., Multoney B., Curtis S., Seeboruth H., Moore S., Daniel B. 2008. Recovery of DNA and Fingerprints from Touched Documents. Forensic Science International: Genetics, 2: 281-285.

[39] Feine I., Shpitzen M., Geller B., Salmon E., Peleg T., Roth J., Gafny R. 2017. Acetone Facilitated DNA Sampling from Electrical Tapes Improves DNA Recovery and Enables Latent Fingerprints Development. Forensic Science International, 276: 107-110.

[40] Ostojic L., Wurmbach E. 2017. Analysis of Fingerprint Samples, Testing Various Conditions, for Forensic DNA Identification. Science and Justice, 57: 35-40. 